\title{
Crystallinity of SiC Coated on Carbon Fiber
}

\author{
Kuniaki HONJO and Akio SHINDO \\ (Government Industrial Research Institute, Osaka) \\ 1-8-31, Midorigaoka, Ikeda-shi, Osaka 563 )
}

\begin{abstract}
The structure, crystallinity and preferred orientation of the $\mathrm{SiC}$ coated on carbon fiber at $1200^{\circ} \mathrm{C}$ from mixtures of monomethyltrichlorosilane, hydrogen, methane and argon were studied by X-ray and selected area electron diffractometries. The $\mathrm{SiC}$ was identified to be $3 \mathrm{C}$ type, in which the stacking sequence of the closest packed layers is highly disordered along one of the [111] directions. Moreover, it was found that a decrease in hydrogen concentration or an increase in methane concentration enhances the orientation of these layers parallel to the fiber surface, and increases the crystallite size. Such changes in the orientation and the crystallite size are considered to be due to the increase in methane concentration in the reaction zone.
\end{abstract}

[Received August 2, 1985]

\section{炭素絨維に被覆した炭化ケイ素の結晶性}

\author{
本城国明・進藤昭男
}

(大阪工業技術試験所)

\begin{abstract}
モノメチルトリクロロシラン, 水素, メタン, アルゴンの混合ガスから $1200^{\circ} \mathrm{C}$ に加熱した炭素 繊維上に $\mathrm{SiC}$ を被覆し, 被覆 $\mathrm{SiC}$ の構造, 結晶性, 配向性をX 線回折法によって調べた. その結果, $\mathrm{SiC}$ は最密充てん面の [111] 方向に沿う積層順序がかなり乱れた $3 \mathrm{C}$ 構造と同定された。更に, ガス中の水素濃度の減少, あるいはメタン濃度の増加によってこの面が瀻維フィラメント表面に平 行に配向するようになること，またそれに伴って結晶子が粗大になることを認めた。このような結 晶子の配向性とサイズの変化は，メタンの過飽和度の増大に起因すると考えられた。
\end{abstract}

(1985 年 8 月 2 日受付)

Key-words : Silicon carbide, Chemical vapor deposition, Coating, Structure, Carbon fiber

\section{Introduction}

Carbon fiber-aluminum composite is possible to produce by a molten-metal infiltration technique, when the wettability of carbon fiber with molten aluminum is improved through a certain surface coating. However, such a surface coating is incompetent to prevent the serious degradation of strength which PAN (polyacrylonitrile)-based carbon fibers undergo by a reaction with aluminum ${ }^{1}$. To overcome this problem, we have studied the coating of carbon fibers with silicon carbide as the barrier against the reaction with aluminum ${ }^{2)}$, and in the cource of this study it has been found that the coating when it deposited at below $1300^{\circ} \mathrm{C}$ has uniform thicknesses on every filaments in the carbon fiber yarn. However, fuller information lacks on the crystallinity or closeness of the coating formed under such condition.

This paper will report the effect of hydrogen and methane concentration in the reaction gas on the crystal structure, the crystallinity and the orientation of silicon carbide coating deposited from monomethyltrichlorosilane on the carbon fibers.

\section{Experimental}

\section{1 Apparatus for coating}

The apparatus used for coating carbon fiber is shown in Fig. 1. The gases of reactants and 


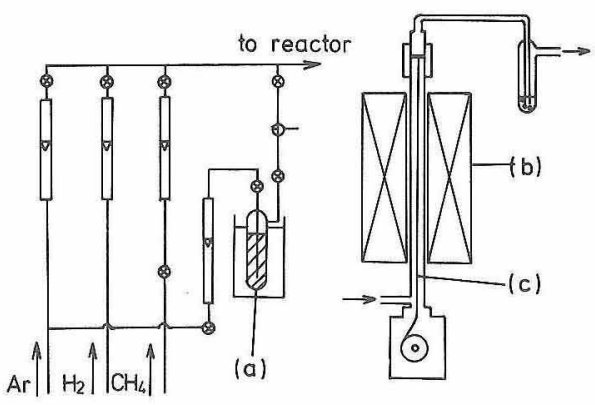

Fig. 1. Apparatus for coating. (a) $\mathrm{CH}_{3} \mathrm{SiCl}_{3}$, (b) furnace, (c) carbon fiber yarn.

carrier were mixed in the line and flowed into the reactor. The flow rates of $\mathrm{Ar}$ and $\mathrm{CH}_{3} \mathrm{SiCl}_{3}$ were 250 and 1.6(STP) $\mathrm{ml} / \mathrm{min}$, respectively. $\mathrm{H}_{2}$ and $\mathrm{CH}_{4}$ were fed at several stages of rates from 0 to 70 , and at rates $0,0.4$ and $1.4 \mathrm{ml} / \mathrm{min}$, respectively. $\mathrm{Ar}, \mathrm{H}_{2}$ and $\mathrm{CH}_{4}$ were of research grade of Matheson $\mathrm{Co} . \mathrm{CH}_{3} \mathrm{SiCl}_{3}$ was of $\mathrm{EP}$ grade of Tokyo Kasei Kogyo Co.

The employed carbon fibers were TORAYCA T 300 and TORAYCA M 40, which are composed of 3000 and 6000 filaments, respectively, of ca. $6.5 \mu \mathrm{m}$ in diameter. They were suspended in the center of a recrystallized alumina tube (Nippon Kagaku Togyo Co.; SSA-S) of $12 \mathrm{~mm}$ in diameter and heated at $1200^{\circ} \mathrm{C}$. In order to avoid the contamination of the deposit by the alumina, the inside of the reaction tube was covered with $\mathrm{SiC}$ by flowing the reaction gas for two hours. The coating on the carbon fibers were carried out thereafter, for $30 \mathrm{~min}$ in each run.

\subsection{Analysis}

The coating on the carbon fibers were analysed for Si by a Molybdenum-blue method after decomposing the coated fibers by molten mixture of $\mathrm{NaNO}_{3}$ and $\mathrm{KOH}$. The coatings were identified and characterized by X-ray diffractometry and $\mathrm{X}$-ray fiber diffraction photograph using $\mathrm{Cu} K \alpha$ radiation generated from Rotaflex of Rigaku Denki Co. Selected area electron diffractometry (SAD) and transmission electron microscopic observation were made by HU-200E electron microscope of Hitachi, Ltd.

\section{Results}

\section{1 Appearance of coating}

Figure 2 shows the scanning electron micrograph of the cross section of the fibers coated at a $\mathrm{H}_{2}$ flow rates of $10 \mathrm{ml} / \mathrm{min}$. Each filament of the fiber is coated with film of equal thickness around

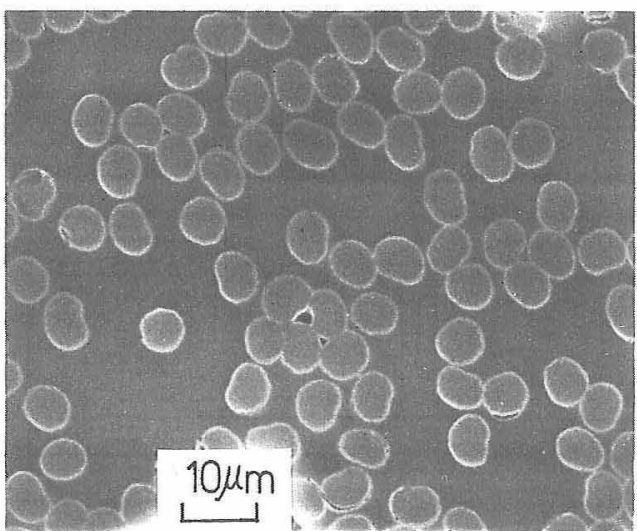

Fig. 2. Cross section of coated carbon fiber.

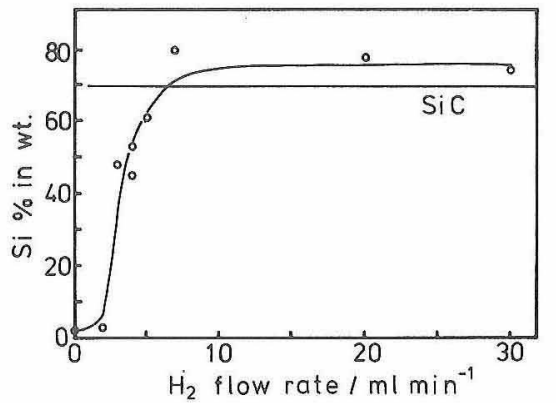

Fig. 3. Variation of Si content in the coating with flow rate of $\mathrm{H}_{2}$.

$0.5 \mu \mathrm{m}$. Cross sections of fibers coated at other flow rates of $\mathrm{H}_{2}$ and $\mathrm{CH}_{4}$ were similar to this figure.

\subsection{Composition of the coated films}

The content of $\mathrm{Si}$ in the films coated in the absence of $\mathrm{CH}_{4}$ addition is plotted in Fig. 3 against the flow rates of $\mathrm{H}_{2}$. The deficiency and the exess of $\mathrm{Si}$ from stoichiometric $\mathrm{SiC}$ composition are due to coexistence of free $\mathrm{C}$ and free $\mathrm{Si}$, respectively. This figure shows that the film coated in the absence of $\mathrm{CH}_{4}$ and at a $\mathrm{H}_{2}$ flow rate of $7 \mathrm{ml} / \mathrm{min}$ has the $\mathrm{SiC}$ composition and this composition is maintained at $\mathrm{H}_{2}$ flow rates up to $30 \mathrm{ml} / \mathrm{min}$ (the deviation from $70 \mathrm{wt} \%$ in this figure is thought to be experimental error). At a flow rate of $50 \mathrm{ml} / \mathrm{min}$, a little amount of codeposited free $\mathrm{Si}$ was detected by X-ray diffractometry.

\subsection{X-ray diffraction}

$\mathrm{X}$-ray diffractometry was carried out on the fibers coated in gas mixtures with or without $\mathrm{CH}_{4}$, the X-ray beam being irradiated vertical to the fiber filaments on glass plates. The diffractograms are shown in Fig. 4.

Each peak was assigned to $3 \mathrm{C}$ polytype of 


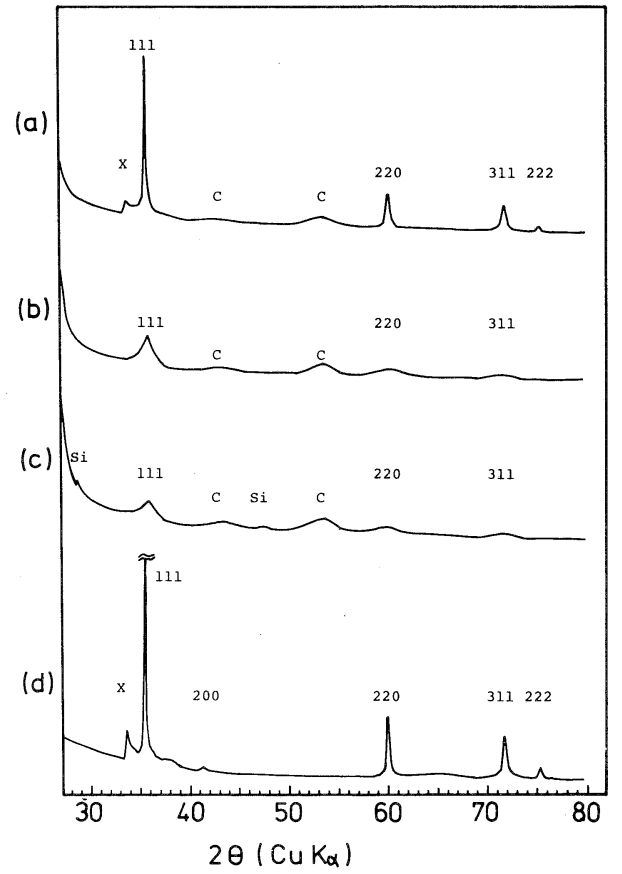

Fig. 4. X-ray diffractograms of the coated fibers. The first and the second values following the letters signify flow rates in $\mathrm{ml} / \mathrm{min}$ of hydrogen and methane, respectively: (a) : 5,0 ; (b) : 20, 0 ; (c) : 50,$0 ;$ (d) :20, 1. 4.

The letters $\mathrm{C}$ and $\mathrm{Si}$ in the figure denote the diffractions due to carbon fiber and co-deposited $\mathrm{Si}$, respectively.

$\mathrm{SiC}$, except the peaks $(d=2.67 \AA)$ marked with $(\mathrm{x})$. The position of such marked peaks coincides with that of 10.0 diffraction of polytypes of $2 \mathrm{H}$, $4 \mathrm{H}$, etc. It should be noted here that the 200 diffraction does not appear or very weakly appears on these patterns as found by the previous investigations $\mathrm{s}^{4,5)}$ on $\mathrm{SiC}$ films deposited at around $1200^{\circ} \mathrm{C}$. These patterns in Fig. 4 show that diffraction lines are sharp when the coating was made at lower rates of $\mathrm{H}_{2}$ in the absence of $\mathrm{CH}_{4}$ (pattern (a)). They are broader at higher flow rates (patterns (b) and (c)), but even at a higher flow rate of $\mathrm{H}_{2}$ they become sharper again by addition of $\mathrm{CH}_{4}$ (pattern (d)).

In Fig. 5, the variation of the half-maximum breadth of 111 diffraction line is shown against $\mathrm{H}_{2}$ flow rate for several amount of $\mathrm{CH}_{4}$ addition. The size of the crystallites coated in the absence of $\mathrm{CH}_{4}$ were estimated from the half maximum breadth of the 111 and 220 diffraction lines of powdered samples, and shown in Fig. 6 against $\mathrm{H}_{2}$ flow rate.

X-ray fiber diffraction photographs on flat films are shown in Figs. $7(\mathrm{a})-(\mathrm{d})$. They correspond to

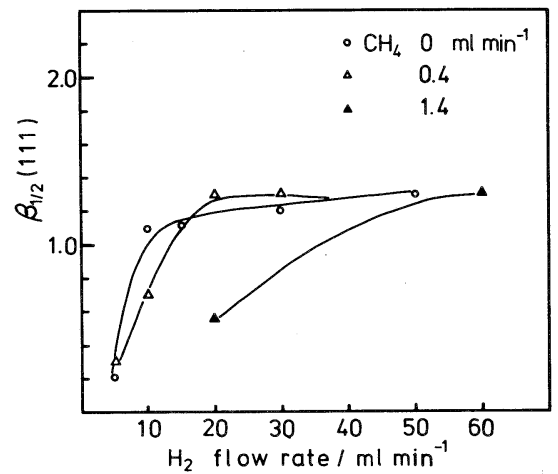

Fig. 5. Variation of the half-maximum breadth of 111 diffraction line of $\mathrm{Cu} K \alpha$ radiation with flow rate of $\mathrm{H}_{2}$.

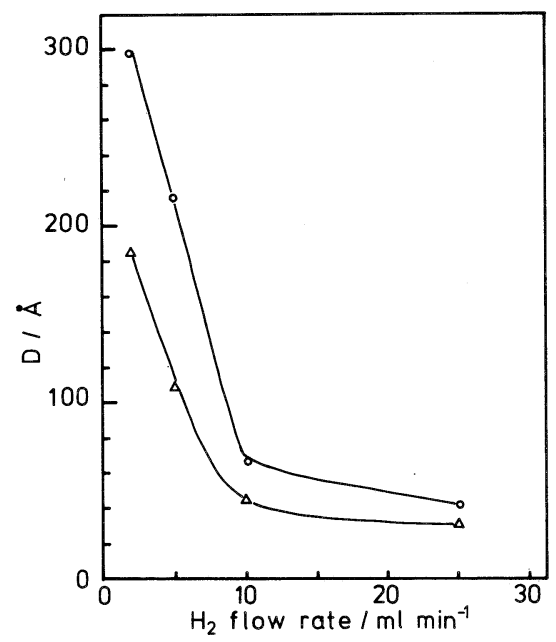

Fig. 6. Variation in crystallite size of the $\mathrm{SiC}$ coated at various flow rates of $\mathrm{H}_{2}$ in the absence of $\mathrm{CH}_{4}$. $\mathrm{O}$ : estimated from 111 diffraction line, $\triangle$ : estimated from 220 line.

the patterns (a)-(d) in Fig. 4, respectively. The film and the coated fiber specimens were placed vertical to the beam of $\mathrm{Cu} K \alpha$ radiation collimated to $1 \mathrm{~mm}$ in diameter. The direction of the axis of the coated carbon fiber is the vertical in the figures.

Figure 7(a) is the pattern of the fiber coated at an $\mathrm{H}_{2}$ flow rate of $5 \mathrm{ml} / \mathrm{min}$. The pattern shows a pair of sharp intensity maxima on the horizontal in the Debye-Scherrer ring of the 111 diffraction of $3 \mathrm{C} \mathrm{SiC}$. This pattern shows that one of the [111] directions of each crystallite is oriented in a direction normal to the fiber axis, and the azimuthal orientation of the crystallites about the [111] is random. Moreover, a broad ring (breadth in $2 \theta=5.3^{\circ}$ ) of weak intensity overlaps the diffraction maxima of 111 diffraction mentioned above. The intensity of this ring is 


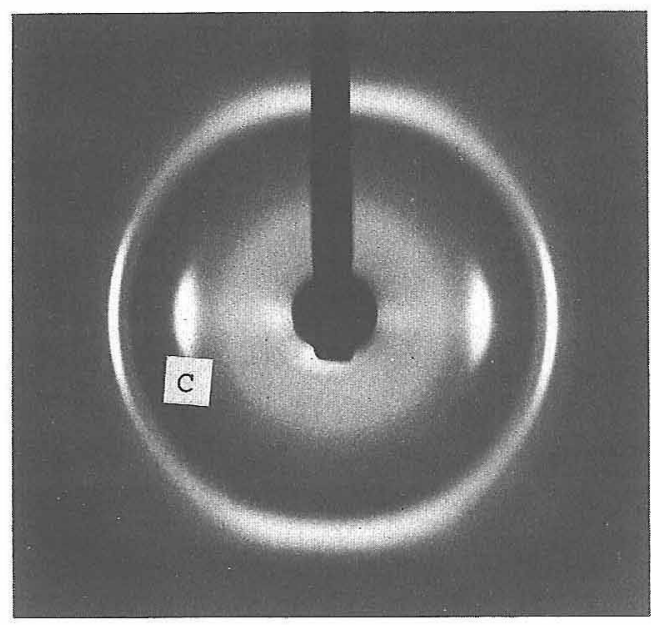

(a)

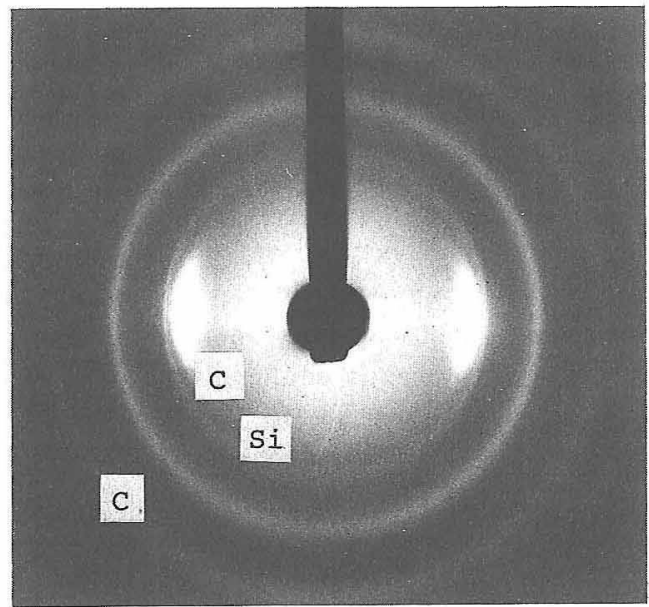

(c)

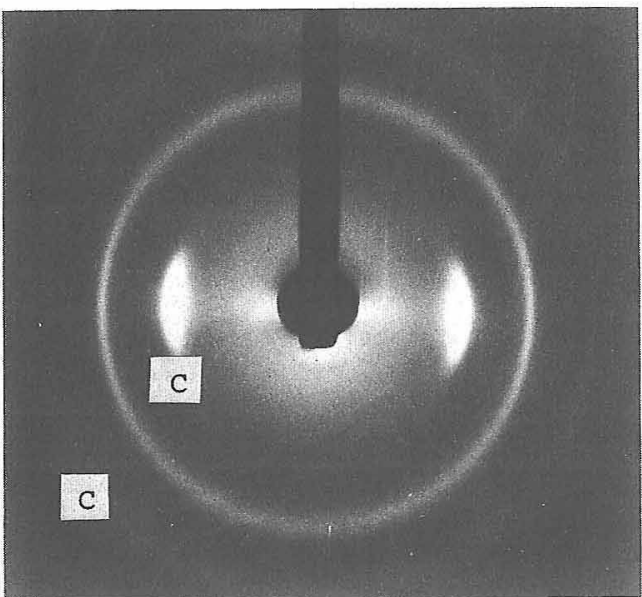

(b)

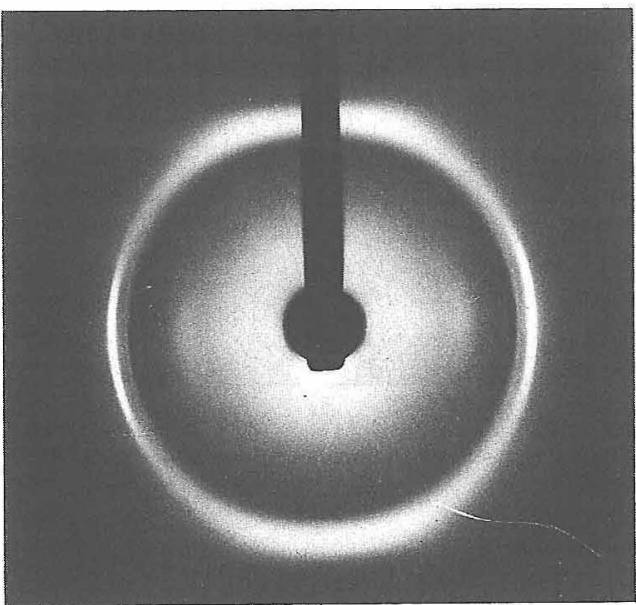

(d)

Fig.7. X-ray fiber diffraction photographs of the coated fiber. The first and the second values following the letters signify flow rates in $\mathrm{ml} / \mathrm{min}$ of hydrogen and methane, respectively : (a) $: 5,0 ;(\mathrm{b}): 20,0 ;(\mathrm{c})$ : 50,$0 ;(d): 20,1.4$.

The ring is due to 111 diffraction $\left(2 \theta=35.7^{\circ}\right)$ of $3 \mathrm{C} \mathrm{SiC}$. The letters $\mathrm{C}$ and $\mathrm{Si}$ in the figure denote the diffractions due to carbon fiber and co-deposited $\mathrm{Si}$, respectively.

strongest at the inner edge and becomes gradually weaker outwards. The diffraction angle of this inner edge coincided with that of the diffraction peak marked $(x)$ in Fig. 4. This unsymmetrical distribution of the intensity across the ring will be discussed later.

Figure $7(b)$ is the pattern of the coating deposited at an $\mathrm{H}_{2}$ flow rate of $20 \mathrm{ml} / \mathrm{min}$. In comparison with Fig. 7(a), this shows slightly parallel orientation of the (111) plane to the fiber axis. At $\mathrm{H}_{2}$ flow rate of $50 \mathrm{ml} / \mathrm{min}$ (Fig. $7(\mathrm{c})$ ), the orientation disappears and $\mathrm{Si}$ co-deposits.

The pattern (d) in Fig. 4, and Fig. 7(d) are the diffractogram and the diffraction photograph of the fiber coated in the same deposition condition as in the fiber of Fig. 7(b), except that $1.4 \mathrm{ml} / \mathrm{min}$ of $\mathrm{CH}_{4}$ was added to the reaction gas mixture in the former case. These figures are practically similar to the patterns of (b) in Fig. 4 (b) and Fig. 7(b), respectively.

It is concluded from these observations that when the flow rate of $\mathrm{H}_{2}$ is so low as to make free carbon deposit, coating is composed mainly of large crystallites of $3 \mathrm{C} \mathrm{SiC}$ with the (111) plane orienting parallel to the fiber axis, and that when $\mathrm{H}_{2}$ flow rate is so high that the coating has $\mathrm{SiC}$ composition or contains free $\mathrm{Si}$, the crystallites become smaller and the preferred orientation 


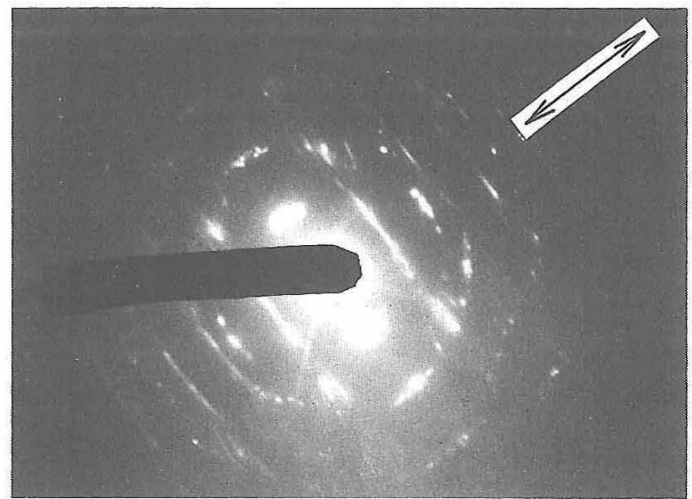

(a)

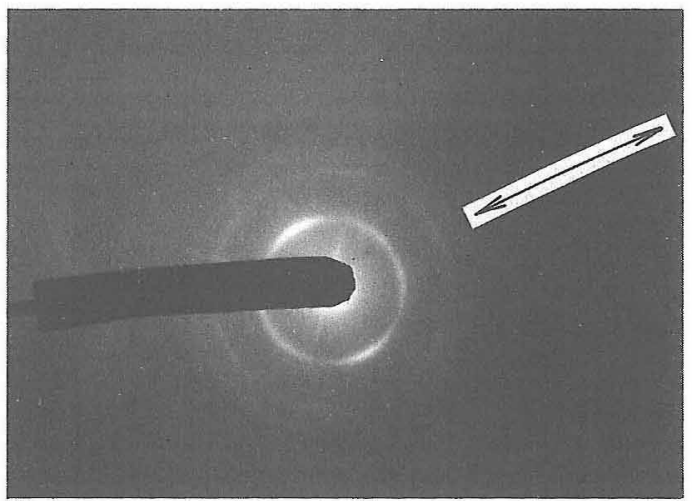

(b)

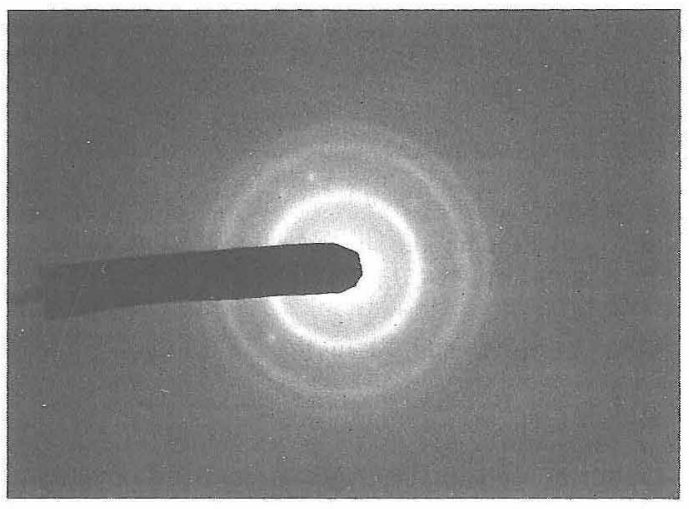

(c)

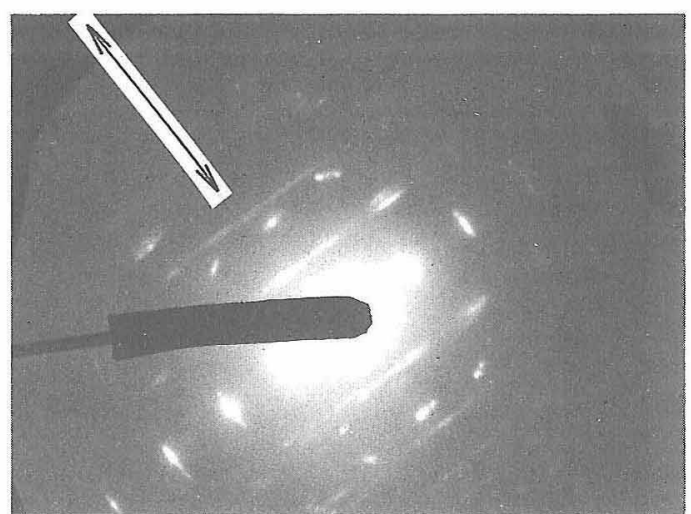

$(d-1)$
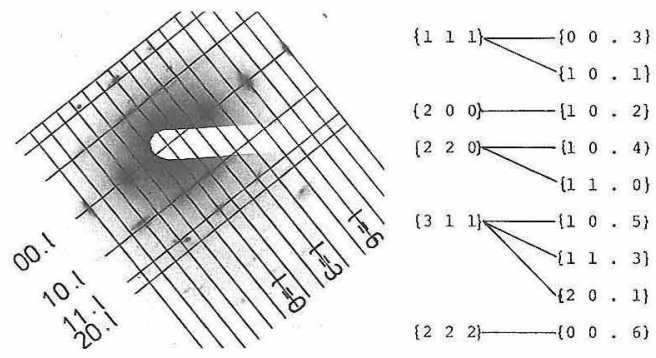

(d-2)

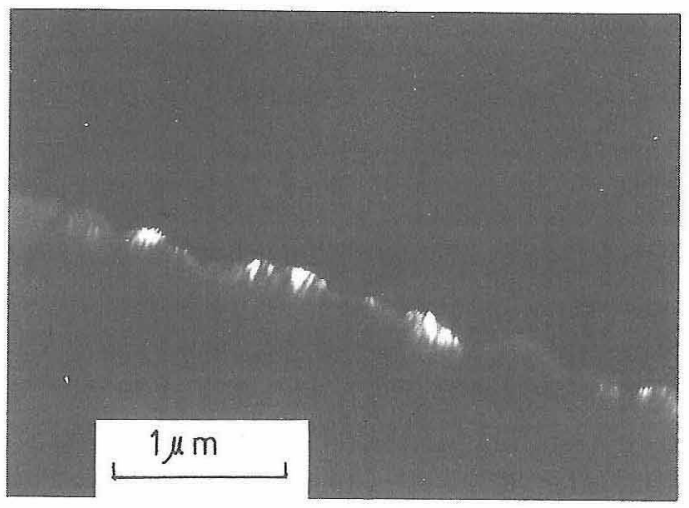

(d-3)

Fig. 8. (a), (b), (c): $\mathrm{SAD}$ patterns of the fibers coated at $\mathrm{H}_{2}$ flow rates of 5,20 and $50 \mathrm{ml} / \mathrm{min}$, respectivery, in the absence of $\mathrm{CH}_{4}$.

$(\mathrm{d}-1),(\mathrm{d}-2)$ : SAD patterns of the fiber coated at flow rates of $\mathrm{H}_{2}$ and $\mathrm{CH}_{4}$ of 20 and $1.4 \mathrm{ml} / \mathrm{min}$, respectively. $(d-3)$ : Dark field image with 00.3 diffraction in $(d-1)$.

disappears gradually. The addition of $\mathrm{CH}_{4}$ into the gas has the same effect on crystallite size and orientation as the decrease of $\mathrm{H}_{2}$ flow rate has.

\subsection{Electron diffraction}

Because of high transmissivity of X-ray, it is impossible to determine the orientation of the (111) plane to the surface of the fiber, or to discuss the structure of the crystallites. SAD from the skin of the coated fiber was employed to overcome these difficulties. For this, single filaments of the coated fibers were set vertical to the electron beam in the transmission electron microscope operated at $175 \mathrm{kV}$.

Figures $8(\mathrm{a})$ and $(\mathrm{d}-1)$ are the $\mathrm{SAD}$ patterns of 
the coated fibers correspond to Figs. 7(a) and (d), respectively. The surface of the filament lies vertical to the figure plane and parallel to the arrow drawn in each figure. These two patterns seem to be essentially identical. As Fig. 8(d-1) typically shows the feature of the patterns, we will discuss on this figure.

The pattern was indexed with hexagonal indices. The relationship between the hexagonal indices and the cubic indices is shown in Fig. 8 $(\mathrm{d}-2)$. It is apparent from this figure that diffractions on $00 . l$ and $11 . l$ rows are discrete spots, while those on $10 . l$ and $20 . l$ rows heavily streak along individual rows. Main spots, including the streaked ones, can be indexed on the basis of $3 \mathrm{C}$ structure as shown in Fig. $8(d-2)$. Since the (00.3) (in hexagonal index) (by cubic index (111)) planes of $3 \mathrm{C} \mathrm{SiC}$ corresponds to three different kind of closest packed layers composed of carbon and silicon atoms ${ }^{6}$, the streaking along the $10 . l$ and $20 . l$ rows means that the stacking sequence of these layers is highly disordered. Discrete spots on the $00 . l$ and $11 . l$ rows also support the idea that the stacking sequence of the closest packed planes are disordered, because it is such a disorder that conserves the planes related by $h-k=3 n^{7)}$.

It is possible that these coating contains "onedimensional disordered" $\mathrm{SiC}$, the structure of which was disclosed by Shinozaki et al. ${ }^{8), 9}$. Moreover, since this figure shows some minor spots in the streak, it might be thought that a trace of some longer-period polytypes is included. But it is also possible that such spots can be arisen from the crystallites misoriented to the fiber surface.

Dark field image with 00.3 (in hexagonal index) (or 111 in cubic index) diffraction are shown in Fig. 8(d-3). Bright column of $c a .200 \AA$ in width extending to $c a .1000 \AA$ perpendicularly to the surface are the single domains in which the above mentioned double layers stack.

Figure $8(b)$ is the SAD pattern of the fiber which gave the X-ray diffraction patterns (b) in Fig. 4 and Fig. 7(b). It is seen that slight orientation of (00.3) (or (111)) plane is observed. The streaks are not seen in this pattern. In Fig. 8(c), which is the pattern of the coating formed at $30 \mathrm{ml} / \mathrm{min}$ of $\mathrm{H}_{2}$, the orientation and the streak disappears. In both of the Figs. 8(b) and (c), no 200 diffraction is observed, as in the X-ray diffraction patterns.

\section{Discussion}

\section{1 Effect of $\mathrm{H}_{2}$ or $\mathrm{CH}_{4}$ in the reactant}

As the result of the present study shows, the orientation of one of the $\{111\}$ planes of $3 \mathrm{C} \mathrm{SiC}$ becomes eminent and the crystallite size becomes larger when the amount of $\mathrm{H}_{2}$ decreased or $\mathrm{CH}_{4}$ was added in the gas mixture.

According to the thermodynamical calculations $^{3), 12}$ on the equilibrium composition of gas in a system comprised of $\mathrm{C}, \mathrm{Si}, \mathrm{Cl}$ and $\mathrm{H}$, the stable species containing $\mathrm{Si}$ or $\mathrm{C}$ are $\mathrm{SiCl}_{2}, \mathrm{SiH}_{3} \mathrm{Cl}$ and $\mathrm{CH}_{4}$ at around $1200^{\circ} \mathrm{C}$. Therefore, the process of forming $\mathrm{SiC}, \mathrm{C}$ and $\mathrm{Si}$ can be illustrated as follows :

$$
\begin{aligned}
& \mathrm{CH}_{3} \mathrm{SiCl}_{3} \rightleftarrows \mathrm{CH}_{4}+\mathrm{SiCl}_{2}\left(\mathrm{SiH}_{3} \mathrm{Cl}\right) \\
& \mathrm{H}_{2}+\mathrm{SiCl}_{2} \rightleftarrows\langle\mathrm{Si}\rangle+\mathrm{HCl} \\
& \mathrm{CH}_{4} \rightleftarrows\langle\mathrm{C}\rangle+\mathrm{H}_{2} \\
& \langle\mathrm{C}\rangle \rightarrow \mathrm{C} \\
& \langle\mathrm{Si}\rangle \rightarrow \mathrm{Si} \\
& \langle\mathrm{Si}\rangle+\langle\mathrm{C}\rangle \rightarrow \mathrm{SiC}
\end{aligned}
$$

( $\langle\mathrm{Si}\rangle$ and $\langle\mathrm{C}\rangle$ denote $\mathrm{Si}$ and $\mathrm{C}$-bearing intermediates adsorbed on the surface.)

These equations suggest, that $\mathrm{H}_{2}$ addition cause the lowering in supersaturation of $\mathrm{CH}_{4}$ (or concentration of $\langle\mathrm{C}\rangle)$ by the equilibriums (2) and $(3)$. Addition of $\mathrm{CH}_{4}$ will increase the supersaturation of $\mathrm{CH}_{4}$ again.

Therefore, the result mentioned above means that the supersaturation of $\mathrm{CH}_{4}$ (or the concentration of C-bearing intermediates) controls the size and orientation of the crystallites.

The estimated crystallite size (Fig.6) shows that the crystallites formed at $25 \mathrm{ml} / \mathrm{min}$ of $\mathrm{H}_{2}$ flow rate are $c a .40 \AA$ in size in both [111] and [220] directions, while the crystallites formed at $2 \mathrm{ml} / \mathrm{min}$ are 300 and $180 \AA$ in these directions, respectivery.

Accordingly, it is concluded that $\mathrm{CH}_{4}$ promotes both the vertical and the in-plane growth of the oriented (111) plane in comparison with the nucleation. It is known that a preferred orientation of the crystallites in a coating can be occurred by the preferred oriented nucleation as in the case of epitaxial growth or by the rapid growth of a particular plane. From the present results we can not decide which is the case. In the latter case $^{10)}$, however, the coating should be random in orientation when the coating thickness is in the range of some $\mu \mathrm{m}$, judging from the result of previously reported study. Therefore, we think that the orientation of the coating may result from the oriented nucleation at the begin- 
ning of the coating.

\subsection{Effect of disordered structure on the diffraction pattern}

The X-ray and the electron diffraction patterns did not show the 200 diffraction of $3 \mathrm{C} \mathrm{SiC}$. As shown in Fig. $8(\mathrm{~d}-2)$, the planes of $\{200\}$ are converted only to $\{10.2\}$ by the hexagonal lattice. Since the diffractions due to these planes are streaked, this will give weak background in the X-ray diffraction pattern and the SAD pattern of randomly oriented crystallites. Other groups of planes in this figure contain planes which are converted to planes with hexagonal indices related by $h-k=3 n$. Since diffraction due to such planes are discrete spots, it is thought that they have shown definite peaks in the X-ray diffraction.

Therefore, the absence of the 200 diffraction peak can be a criterion of the disordered stacking structure. Thus, the absence of this diffraction in Figs. 4, 7, 8(b) and (c) indicates that these crystallites are also one-dimensionally disordered.

Though the peaks marked ( $\mathrm{x}$ ) in Fig. 4 can be due to 10.0 diffraction of $\alpha$-polytypes, such as $2 \mathrm{H}$ or $4 \mathrm{H}$, no peaks due to other diffractions expected for these polytypes are observed. Therefore, this peak is considered to be arisen from the streaks passing through the 10.0 point as shown in Figs. $8(\mathrm{a}),(\mathrm{d}-1)$ and $(\mathrm{d}-2)$. The broad tails following this peak observed in Figs. 4, 7(a) and (d) will also arise from these streaks, as reported for the origin of an unsymmetrical DebyeScherrer ring of random-layered carbon ${ }^{11}$.

According to Shinozaki et al. ${ }^{8)}$, one-dimensional disordered $\mathrm{SiC}$ itself is composed of randomly stacked $3 \mathrm{C}$-phase and $\alpha$-type-phases lamellae, the contents of which vary with materials. Therefore, in addition to $3 \mathrm{C}$-phase which is considered to be an important contributor to the intensity modulation of the streaks in Figs. 8(a), $(d-1)$ and $(d-2)$, it is probable that $\alpha$-type-phases make some contribution to these streaks.

\section{Summary and conclusion}

The crystallinity and orientation of $\mathrm{SiC}$ coated from $\mathrm{CH}_{3} \mathrm{SiCl}_{3}$ on carbon fiber at $1200^{\circ} \mathrm{C}$ was investigated and the following conclusions were obtained :

(1) The content of free carbon in the coating increased with decreasing amount of $\mathrm{H}_{2}$ in the reaction gas.

(2) The deposited $\mathrm{SiC}$ has 3C polytype structure in which the stacking order of the closest packed layers composed of carbon and silicon atoms is highly disordered along one [111] direction.

(3) The decrease in the amount of $\mathrm{H}_{2}$ or increase in $\mathrm{CH}_{4}$ in the reaction gas makes the $\mathrm{SiC}$ crystallites large in three dimensions, and makes the planes of the closest packed layers parallel to the fiber surface.

(4) The change in the amount of $\mathrm{H}_{2}$ or $\mathrm{CH}_{4}$ is considered to change the supersaturation of $\mathrm{CH}_{4}$ in the reaction zone. This will cause the change in the orientation and the crystallinity of the $\mathrm{SiC}$ crystallites.

\section{References}

1) N. F. Amateau, J. Composite Mater., 10, 279-96 (1976).

2) K. Honjo and A. Shindo, Preprints of the Annual Meeting of the Ceramic Society of Japan, Yokohama (1980) p. 39.

3) W.F. Knippenberg, G. Verspui and A. W. C. von Kemenade, Proc. 3rd. Intern. Conf. Silicon Carbide, Miami, Sept. (1973) p. 92-107.

4) J. Chin, P. K. Gantzel and R. G. Hudson, Thin Solid Films, 40, 57-72 (1977).

5) K. Shodo, Nippon Kinzoku Gakkai Shi, 42, 131-36 (1978).

6) A.R. Verma and P. Krishna, "Polymorphism and Polytypism in Crystals", Wiley, N. Y. (1966).

7) J. Kakinoki, in "X-ray Cryatallography, Vol.2", Ed. I. Nitta, Maruzen, Tokyo (1961) p. 664.

8) S. Shinozaki and K. R. Kinsman, Acta Met. , 26, 769-76 (1978).

9) S. Shinozaki and H. Sato, J. Am. Ceram. Soc., 61, 425-29 (1978).

10) A. van der Drift, Philips Research Reports, 22, 267-88 (1967).

11) J. Kakinoki, K. Katada and T. Hanai, Acta Cryst., 13, 448-49 (1960).

12) G. S. Fishman and W. T. Petuskey, J. Am. Ceram. Soc., 68, 185-90 (1985). 